\section{Herbaceous Perennial Seed Germination and Seedling Growth in Biochar-amended Propagation Substrates}

\author{
Benjamin K. Hoover ${ }^{1}$ \\ Department of Horticulture and Crop Science, California Polytechnic State \\ University, 1 Grand Avenue, San Luis Obispo, CA 93407
}

Additional index words. Coreopsis grandiflora, Eschscholzia californica, Leucanthemum $\times$ superbum, tickseed, california poppy, shasta daisy, floriculture, digital imaging, image analysis, scan analysis

\begin{abstract}
The first objective of this study was to assess the effects of coconut shell biochar in propagation substrate on seed germination and seedling growth of Coreopsis grandiflora (Hogg ex Sweet) 'Early Sunrise', Leucanthemum $\times$ superbum (Bergman ex J. Ingram) 'Silver Princess', and Eschscholzia californica (Cham.). Cornell seed germination mix was amended with the biochar $(0 \%, 5 \%, 10 \%, 20 \%$, or $40 \%$, v/v). Seed germination and seedling growth were determined during a 21-day period in two germination rooms. This particular biochar amendment did not affect final germination percentage for any of the species. All three species had seedling shoot and primary root length growth with low to moderate positive correlation $(r=0.33-0.54)$ with coconut shell biochar amendment volume. Coreopsis seedling dry weight was significantly higher with $40 \%$ biochar than the control $(P \leq 0.05)$. The second objective of the study was to compare digitally collected data with manually collected data. Two-dimensional scans of Coreopsis and Leucanthemum seedlings were collected. Seedling dry weight $(\mathrm{mg})$ and seedling length $(\mathrm{mm})$ predicted seedling two-dimensional area for Coreopsis $\left(R^{2}=0.73\right.$, $P<0.001)$ and Leucanthemum $\left(R^{2}=0.87, P<0.001\right)$. Digitally traced shoot and root lengths were strongly positively correlated $(r=0.99-0.97)$ with manual ruler measurements, suggesting that digital imaging could replace manual length measurements. The results of this study suggest inclusion of this particular coconut shell biochar in seed germination, and establishment substrates can have neutral or positive effects on herbaceous perennial germination and establishment.
\end{abstract}

Floriculture crops had a wholesale value of $\$ 4.4$ billion in the United States in 2015 (U.S. Department of Agriculture, 2016). The floriculture industry produces many crops using specialized substrates, and many of these crops are produced from seeds. An ideal seed propagation substrate is firm enough to support a seed, allows for gas exchange to ensure oxygen is present for developing roots, holds water to facilitate hydration of the seed without promoting anoxia, is free of pathogens, and is economical (Hartmann et al., 2011). Sphagnum peat, perlite, and vermiculite are commonly used in propagation substrates. Growing concern about the economic and environmental costs of these ingredients has fueled interest in alternative substrate materials (Landis and Morgan, 2009; Owen et al., 2016). One alternative product may be biochar (Altland

Received for publication 16 Oct. 2017. Accepted for publication 23 Dec. 2017.

This research was partially funded by the California Association of Nurseries and Garden Centers and the California State University Agricultural Research Institute (ARI).

${ }^{1}$ Corresponding author. E-mail: bkhoover@calpoly. edu.
Santiago and Santiago, 1989). It has been tested as a replacement for vermiculite (Headlee et al., 2014), perlite (Northup, 2013), and peat (Steiner and Harttung, 2014; Vaughn et al., 2013). In container production settings, it can have favorable chemical and physical properties, and plant growth has been unchanged or increased compared with controls (Dumroese et al., 2011; Graber et al., 2010; Headlee et al., 2014; Vaughn et al., 2013).

Most research testing biochar or other forms of PCM in seed propagation or plant establishment substrates has focused on ecological or field agricultural applications, as opposed to soilless substrate culture in containers. Seed germination studies with potato (Solanum tuberosum L.; Bamberg et al., 1986) and sunflower (Helianthus annuus L.; Alburquerque et al., 2014) have shown increased germination rates when activated charcoal was added to the respective substrates. Keeley and Pizzorno (1986) reported increased germination of herbaceous California chaparral plant seeds [Emmenanthe penduliflora Benth. and Eriophyllum confertiflorum (DC.) A. Gray] when exposed to char or heat-treated wood products in screened potting soil. They concluded that the presence of heated xylan and glucuronic acid were involved in promoting germination. Two studies have reported an increase in wheat (Triticum aestivum L.) germination in soils amended with biochar (Solaiman et al., 2012; Van Zwieten et al., 2010). Nair and Carpenter (2016) reported that germination increases in peppers (Capsicum annuum L.) produced in cell trays with soilless mixes amended with hardwood biochar, whereas Liopa-Tsakalidi and Barouchas (2017) reported that pepperoncini (C. annuum L. 'Stavros') germination increases in an acidic soil amended with wood chip biochar and no germination change in alkaline soil amended with the same biochar. Also, biochar addition has resulted in no significant changes in maize (Zea mays L.), soybean [Glycine max (L.) Merr.], radish (Raphanus sativus L.), mung bean [Vigna radiata (L.) R. Wilczek], sunflower, or wheat germination (Free et al., 2010; Paneque et al., 2016; Solaiman et al., 2012; Van Zwieten et al., 2010). A reduction in germination percentage after biochar amendment has been reported for mung bean, subterranean clover (Trifolium subterraneum L.), and wheat (Solaiman et al., 2012).

Plant establishment and growth in substrates amended with biochar or other forms of PCM have been variable. Increases in fresh and dry weight, root length, and plant height have been reported, as well as decreases. The rate of biochar inclusion, base substrate or soil, biochar volatile matter, biochar-free radicals, synergistic effect with fertilizers, and crop selection have all been identified as factors (Deenik et al., 2010; Liao et al., 2014; Solaiman et al., 2012; Van Zwieten et al., 2010). The effect of differences in biochar feedstock, processing, and physical properties between experiments is not known.

Plant establishment and growth study data are often collected as plant height (Graber et al., 2010; Sun et al., 2014; Vaughn et al., 2013), dry 
Table 1. End-of-study physical and chemical properties of cornell seed germination mix amended with coconut shell biochar used in germination and seedling growth experiments.

\begin{tabular}{|c|c|c|c|c|c|c|c|c|c|c|}
\hline $\begin{array}{l}\text { Substrate biochar } \\
(\%, v / v)\end{array}$ & $\mathrm{pH}^{\mathrm{z}}$ & $\begin{array}{l}\text { Conductivity } \\
\left(\mathrm{mS} \cdot \mathrm{cm}^{-1}\right)\end{array}$ & $\begin{array}{l}\text { Total exchangeable } \\
\text { cations }\left(\mathrm{meq} \cdot \mathrm{kg}^{-1}\right)\end{array}$ & \multicolumn{5}{|c|}{$\left(\mathrm{mg} \cdot \mathrm{kg}^{-1}\right)$} & $\mathrm{C} / \mathrm{N}$ ratio & $\begin{array}{c}\text { Dry bulk } \\
\text { density }\left(\mathrm{kg} \cdot \mathrm{m}^{-3}\right)\end{array}$ \\
\hline 0 & $6.0 \pm 0.1$ & $0.27 \pm 0.03$ & 369 & 489 & 135 & 1,029 & 4,606 & 979 & 28.4 & 189.8 \\
\hline 5 & $6.1 \pm 0.1$ & $0.24 \pm 0.02$ & 260 & 279 & 124 & 1,310 & 3,121 & 703 & 49.0 & 227.2 \\
\hline 10 & $6.0 \pm 0.1$ & $0.26 \pm 0.01$ & 240 & 289 & 150 & 1,433 & 2,729 & 617 & 60.9 & 255.1 \\
\hline 20 & $6.1 \pm 0.1$ & $0.27 \pm 0.02$ & 210 & 256 & 107 & 1,675 & 2,170 & 481 & 87.9 & 310.3 \\
\hline 40 & $6.0 \pm 0.1$ & $0.25 \pm 0.02$ & 146 & 55 & 112 & 1,815 & 1,201 & 327 & 80.1 & 417.1 \\
\hline
\end{tabular}

${ }_{\mathrm{z}}^{\mathrm{z}} 1: 5$ dilution testing (substrate to deionized water), $n=5$.

${ }^{\mathrm{y}} 1: 5$ dilution testing (substrate to deionized water), $n=5$.

Table 2. Final germination (\%) and Timson's index means for herbaceous seedlings after 3 weeks of growth in cornell seed germination mix amended with coconut shell biochar $(\mathrm{v} / \mathrm{v})$ repeated in two germination rooms $(\mathrm{GRs})$, with SD $(n=10)$.

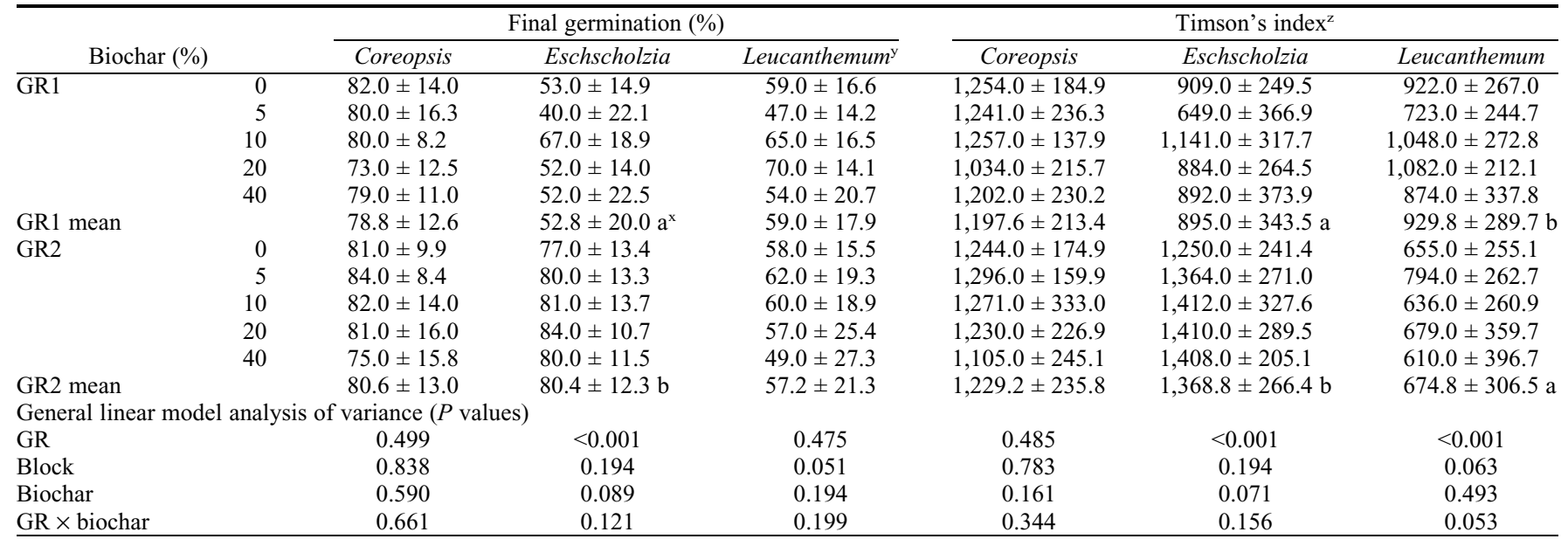

${ }^{\mathrm{z}}$ Timson's index $=\Sigma n(n=$ cumulative daily germination percentage for each day in the experiment).

${ }^{y}$ Data were square root transformed to meet normality assumption for analysis, nontransformed means reported.

${ }^{x}$ Means in each column that do not share a letter are significantly different based on Tukey's studentized range test $(P \leq 0.05)$.

Table 3. Primary shoot and primary root length $(\mathrm{mm})$ means for herbaceous seedlings after 3 weeks of growth in cornell seed germination mix amended with coconut shell biochar (v/v) repeated in two germination rooms (GRs), with SD $(n=10)$.

\begin{tabular}{|c|c|c|c|c|c|c|c|}
\hline \multirow{2}{*}{\multicolumn{2}{|c|}{ Biochar (\%) }} & \multicolumn{3}{|c|}{ Shoot length $(\mathrm{mm})$} & \multicolumn{3}{|c|}{ Root length (mm) } \\
\hline & & Coreopsis & Eschscholzia & Leucanthemum & Coreopsis & Eschscholzia & Leucanthemum \\
\hline \multirow[t]{5}{*}{ GR1 } & 0 & $16.6 \pm 3.1 \mathrm{a}^{\mathrm{z}}$ & $42.5 \pm 13.1 \mathrm{a}$ & $15.3 \pm 6.0 \mathrm{ab}$ & $12.6 \pm 2.7 \mathrm{a}$ & $13.9 \pm 4.4 \mathrm{a}$ & $12.3 \pm 4.0 \mathrm{ab}$ \\
\hline & 5 & $15.9 \pm 3.8 \mathrm{a}$ & $32.0 \pm 11.0 \mathrm{a}$ & $10.7 \pm 3.1 \mathrm{a}$ & $12.0 \pm 3.5 \mathrm{a}$ & $13.0 \pm 3.2 \mathrm{a}$ & $9.7 \pm 3.0 \mathrm{a}$ \\
\hline & 10 & $25.5 \pm 1.9 \mathrm{c}$ & $75.2 \pm 5.0 \mathrm{~b}$ & $22.5 \pm 4.6 \mathrm{~cd}$ & $19.2 \pm 3.3 b$ & $30.0 \pm 4.8 \mathrm{bcd}$ & $20.2 \pm 5.1 \mathrm{bc}$ \\
\hline & 20 & $22.4 \pm 4.9 \mathrm{bc}$ & $75.0 \pm 8.8 b$ & $21.1 \pm 3.4 \mathrm{bcd}$ & $19.5 \pm 2.0 \mathrm{~b}$ & $30.6 \pm 4.1 \mathrm{bcd}$ & $22.8 \pm 6.6 \mathrm{~cd}$ \\
\hline & 40 & $25.9 \pm 1.7 \mathrm{c}$ & $72.3 \pm 9.3 b$ & $23.9 \pm 7.2 \mathrm{~d}$ & $22.0 \pm 3.6 \mathrm{bc}$ & $26.9 \pm 3.8 \mathrm{bc}$ & $30.1 \pm 5.8 \mathrm{~d}$ \\
\hline \multirow[t]{5}{*}{ GR2 } & 0 & $22.8 \pm 2.0 \mathrm{bc}$ & $63.7 \pm 8.1 \mathrm{a}$ & $17.5 \pm 4.2 \mathrm{bcd}$ & $21.9 \pm 2.1 \mathrm{bc}$ & $25.6 \pm 5.3 b$ & $17.5 \pm 4.6 \mathrm{abc}$ \\
\hline & 5 & $21.9 \pm 1.8 \mathrm{bc}$ & $69.9 \pm 6.4 \mathrm{a}$ & $18.8 \pm 2.2 \mathrm{bcd}$ & $26.7 \pm 3.0 \mathrm{~d}$ & $29.5 \pm 5.2 \mathrm{bcd}$ & $21.7 \pm 5.5 \mathrm{c}$ \\
\hline & 10 & $21.0 \pm 1.8 \mathrm{~b}$ & $72.1 \pm 4.8 \mathrm{a}$ & $17.0 \pm 2.7 \mathrm{abc}$ & $26.1 \pm 3.6 \mathrm{~cd}$ & $28.7 \pm 4.7 \mathrm{bcd}$ & $19.5 \pm 2.4 \mathrm{bc}$ \\
\hline & 20 & $21.3 \pm 2.7 \mathrm{~b}$ & $70.9 \pm 7.0 \mathrm{a}$ & $19.8 \pm 4.3 \mathrm{bcd}$ & $28.9 \pm 3.2 \mathrm{~d}$ & $33.3 \pm 6.5 \mathrm{~cd}$ & $22.3 \pm 5.4 \mathrm{~cd}$ \\
\hline & 40 & $23.5 \pm 2.2 \mathrm{bc}$ & $70.0 \pm 5.9 \mathrm{a}$ & $17.6 \pm 4.1 \mathrm{bcd}$ & $29.4 \pm 5.2 \mathrm{~d}$ & $35.0 \pm 6.8 \mathrm{~d}$ & $22.6 \pm 10.8 \mathrm{~cd}$ \\
\hline \multicolumn{8}{|c|}{ General linear model analysis of variance ( $P$ values $)$} \\
\hline GR & & 0.140 & $<0.001$ & 0.546 & $<0.001$ & $<0.001$ & 0.131 \\
\hline Block & & 0.438 & 0.901 & 0.559 & 0.170 & 0.038 & 0.227 \\
\hline Biochar & & $<0.001$ & $<0.001$ & $<0.001$ & $<0.001$ & $<0.001$ & $<0.001$ \\
\hline GR $\times$ biochar & & $<0.001$ & $<0.001$ & $<0.001$ & 0.002 & $<0.001$ & $<0.001$ \\
\hline
\end{tabular}

${ }^{\mathrm{z}}$ Means in each column that do not share a letter are significantly different based on Tukey's studentized range test $(P \leq 0.05)$.

weight (Alburquerque et al., 2014; Chan et al., 2008; Deenik et al., 2010; Free et al., 2010; Graber et al., 2010; Van Zwieten et al., 2010; Vaughn et al., 2013), root length (Free et al., 2010; Solaiman et al., 2012), or leaf area (Graber at al., 2010; Paneque et al., 2016). Herbaceous perennial seedling dry weights are often less than $1 \mathrm{mg}$ (Fenner, 1983; Gross, 1984), resulting in tedious laboratory work with samples that are difficult to retain after weighing. One alternative to dry weight analysis is digital imaging, which is less tedious and allows for lasting records of samples (Judd et al., 2015).
Digital imaging and analysis have been used to quantify plant growth in micropropagation (Smith et al., 1989), aquatic plant establishment (Sher-Kaul et al., 1995), and in plant phenotyping studies (Golzarian et al., 2011; Leister et al., 1999). The equipment and software required ranged widely and in some cases, the software may be free (Tajima and Kato, 2011). Digital imaging allows seedling length and two-dimensional area data to be easily calculated with software. To date, most biochar studies with plant growth rely on weight or length measurement data as dependent variables, so it is important to understand how two-dimensional area data correlate with these metrics.

Biochar use in container plant production is promising, but more research is needed in the context of ornamental plant propagation. The species in this study were selected from the ornamental perennial plant industry $(\mathrm{Co}$ reopsis grandiflora Hogg ex Sweet 'Early Sunrise' and Leucanthemum Xsuperbum Bergman ex J. Ingram 'Silver Princess') and the restoration and revegetation industry (Eschscholzia californica Cham.; Montalvo 
et al., 2002) because their germination and seedling establishment responses to a PCM have not been documented. The primary objective was to assess the effects of coconut shell biochar in propagation substrate on seed germination and seedling growth for these three species. A secondary objective was to examine the relationship between digital imaging data and traditional, manually collected data.

\section{Materials and Methods}

A germination study comprising three experiments was conducted in two germination rooms (GRs) in California. GR1 (July 2015) was in San Luis Obispo and GR2 (Nov. to Dec. 2015) was in Arroyo Grande. The GRs were climate controlled, contained benches with bottom-heat mats, and had cool white fluorescent lighting (Toole, 1963). The GR1 mean air temperature was $24.5^{\circ} \mathrm{C}(1.1 \mathrm{sD})$, mean substrate temperature was $24.6{ }^{\circ} \mathrm{C}(1.1$ SD), mean relative humidity ( $\mathrm{RH}$ ) was $72.9 \%$ (9.4 SD), and the 24-h mean photosynthetically active radiation $(P A R)$ level was 14.0 $\mu \mathrm{mol} \cdot \mathrm{m}^{-2} \cdot \mathrm{s}^{-1}$. The GR2 mean air temperature was $21.0^{\circ} \mathrm{C}(1.2 \mathrm{SD})$, mean substrate temperature was $21.2{ }^{\circ} \mathrm{C}(1.1 \mathrm{sD})$, mean $\mathrm{RH}$ was $65.3 \%$ (4.3 SD), and the 24-h mean PAR level was $15.9 \mu \mathrm{mol} \cdot \mathrm{m}^{-2} \cdot \mathrm{s}^{-1}$.

Seeds and substrates. Seeds of C. grandiflora 'Early Sunrise', Leucanthemum ×superbum 'Silver Princess' (W. Atlee Burpee \& Co., Warminster, PA), and E. californica (Anderson's Seed Co., Escondido, CA) were obtained from commercial suppliers. The base substrate was an adapted cornell seed germination mix (Boodley and Sheldrake, 1982). The ingredients were sphagnum peat (Sunshine Canadian Sphagnum Peat Moss Grower Grade White; Sun Gro, Sacramento, CA) and fine vermiculite (Premium Grade Fine; Ultra Tech Vermiculite, Richmond, CA) mixed 1:1 $(\mathrm{v} / \mathrm{v}), 413.0 \mathrm{~g} \cdot \mathrm{m}^{-3}$ calcium nitrate $(15 \mathrm{~N}-0 \mathrm{P}-0 \mathrm{~K})$, $413.0 \mathrm{~g} \cdot \mathrm{m}^{-3}$ triple superphosphate $(0 \mathrm{~N}-19.7 \mathrm{P}-$ $0 \mathrm{~K}), 2378.1 \mathrm{~g} \cdot \mathrm{m}^{-3}$ dolomite, and $50.1 \mathrm{~g} \cdot \mathrm{m}^{-3}$ micronutrient mix (Micromax Plus; Grace Sierra, Milpitas, CA) containing P (1.7\%),

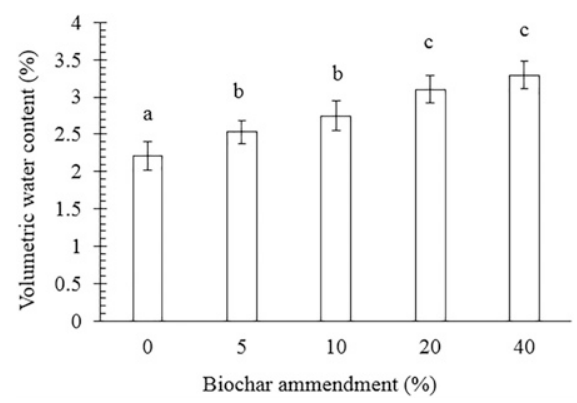

Fig. 1. Volumetric water content of ovendried cornell seed germination mix amended with coconut shell biochar $(0 \%, 5 \%, 10 \%, 20 \%$, $40 \%, \mathrm{v} / \mathrm{v}$ ) after $7 \mathrm{~d}$ at $72 \%$ atmospheric relative humidity. Error bars show \pm SD. Means in each chart that do not share a letter are significantly different based on a Tukey's studentized range test $(P \leq 0.05 ; n=5)$.
$\mathrm{Ca}(16.0 \%), \mathrm{Mg}(8.0 \%), \mathrm{S}(1.5 \%), \mathrm{B}(0.02 \%)$, $\mathrm{Cu}(0.07 \%), \mathrm{Fe}(1.80 \%), \mathrm{Mn}(0.3 \%), \mathrm{Mo}$ $(0.007 \%)$, and $\mathrm{Zn}(0.1 \%)$.

The base mix was amended with biochar from a commercial supplier (Bay Area Biochar, Concord, CA) at rates of $0 \%, 5 \%, 10 \%$, $20 \%$, or $40 \%(\mathrm{v} / \mathrm{v})$. The biochar was made from coconut shell feedstock treated to fast pyrolysis at $\approx 600{ }^{\circ} \mathrm{C}$, then ground to small particles and acidified. The chemical and physical properties of the biochar were analyzed by a commercial laboratory (Waypoint Analytical, Anaheim, CA): pH: 6.4; dry bulk density: $362.1 \mathrm{~kg} \cdot \mathrm{m}^{-3}$; $\mathrm{C} / \mathrm{N}$ ratio: 107.6 ; total exchangeable cations: $95 \mathrm{meq} \cdot \mathrm{kg}^{-1}$; and dry weight percentage passing screen sizes: $6.4 \mathrm{~mm}(99.8 \%), 4.8 \mathrm{~mm}(99.4 \%), 2.4 \mathrm{~mm}$ (97.7\%), $1.0 \mathrm{~mm}(37.5 \%)$, and $0.5 \mathrm{~mm}$ (15.4\%). The biochar was a coarse powder according to the classification system proposed by Camps-Arbestain et al. (2015).

Sphagnum peat and biochar were screened to a maximum particle size of $6 \mathrm{~mm}$ before use. At the conclusion of the study, substrate samples were sent to a commercial laboratory for chemical and physical analysis (Waypoint Analytical). Additional pH (IQ150; Spectrum Technologies, Inc., Aurora, IL) and electrical conductivity (2265FS; Spectrum Technologies, Inc.) substrate testing was conducted using 1:5 (substrate:deionized water, v/v) diluted samples (Table 1).

Experimental design and setup. Each species was treated as a separate experiment with 10 replicates. The experiments were randomized complete block designs, with blocks and biochar substrate amendment as independent factors. Seeds were sown in 7.9-cm-deep square pots with a volume of $538 \mathrm{~cm}^{3}$ (SVT-400; T.O. Plastics, Inc., Clearwater, MN). Each pot was an experimental unit with 10 seeds, and the seeds were observational units. Seeds were lightly covered $(2 \mathrm{~mm})$ with coarse vermiculite after sowing (Vermiculite 3 Medium; Therm-O-Rock Industries, Inc., Chandler, AZ). Misting was provided on a weekly basis in GR1 and twice weekly in GR2. Each experimental unit received $\approx 5 \mathrm{~mL}$ of water per misting.

Data collection. Data were collected daily as the number of seeds visibly germinated in each pot. The emergence of any plant structure from the seedcoat was considered visible germination (Bewley et al., 2013). The seedlings were removed from the substrate after $21 \mathrm{~d}$, and any substrate particles clinging to the root system were gently removed with a soft brush and a spray bottle. Mean seedling primary root length and primary shoot length for each experimental unit were measured manually to the closest millimeter using a ruler.

After the experiments in GR2, seedling roots and shoots were separated with a razor after they were manually measured. The roots and shoots from each experimental unit were then placed on a transparent cellulose acetate

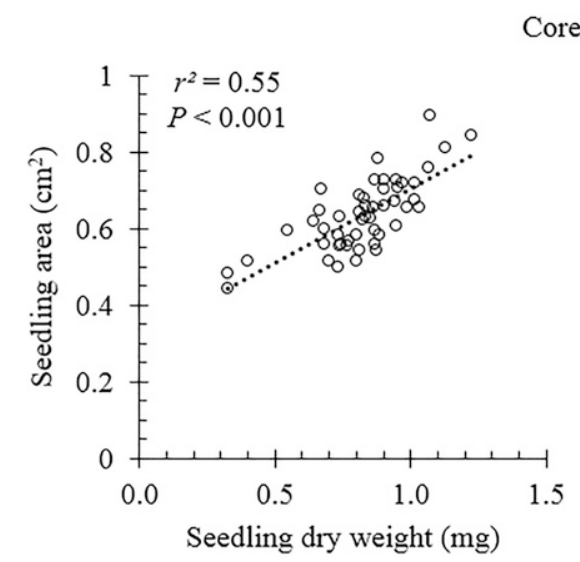

\section{Coreopsis}
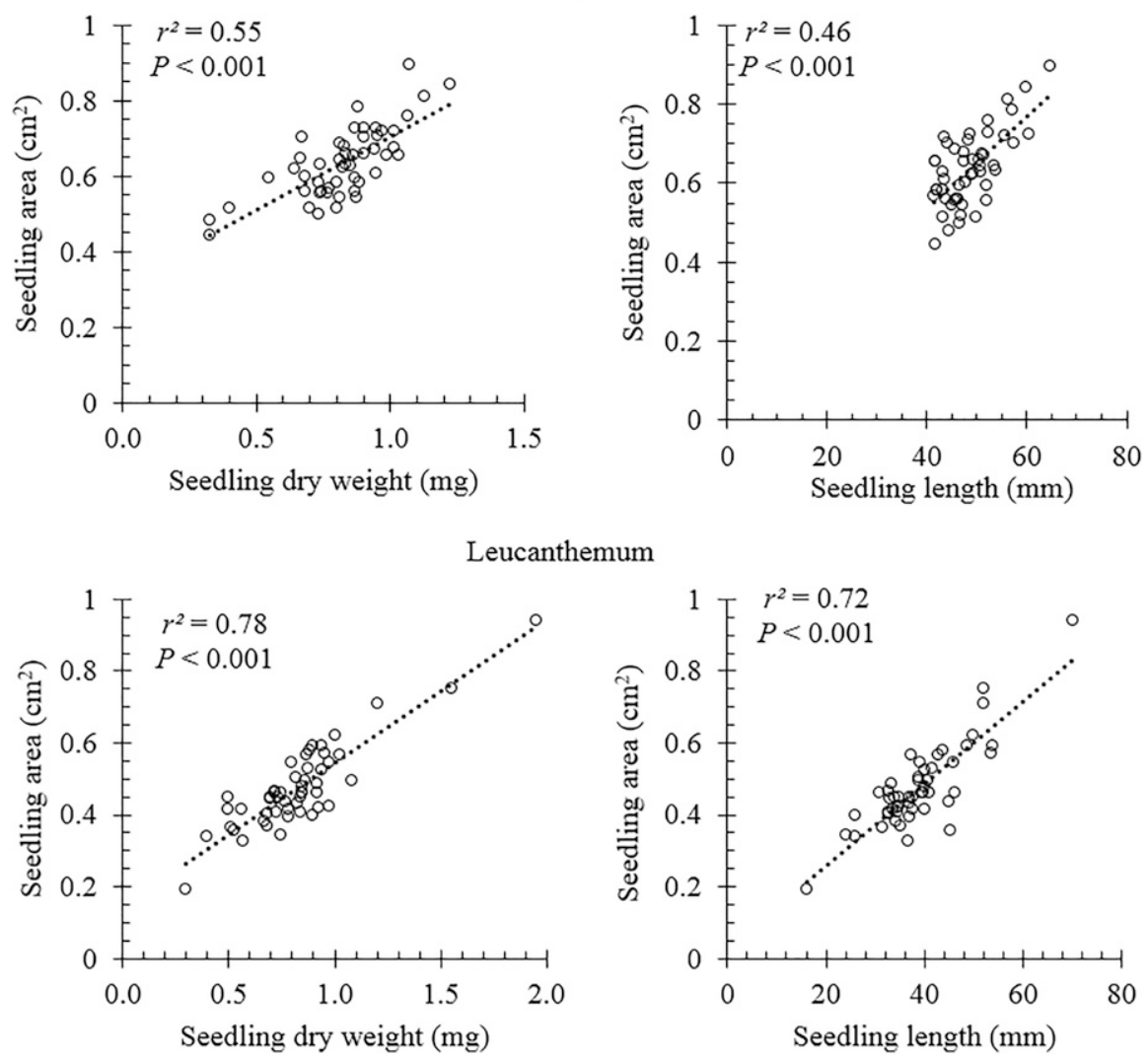

Fig. 2. Regression of Coreopsis grandiflora and Leucanthemum $\times$ superbum seedling dry weight (mg) and seedling length $(\mathrm{mm})$ as predictors of seedling two-dimensional area $\left(\mathrm{cm}^{2} ; n=10\right)$. 
sheet taking care to avoid overlapping the plant tissues. They were subsequently scanned at 600 dpi against a white background (Epson Perfection V19; Epson America, Inc., Long Beach, CA). Seedling tissue was oven dried at $50{ }^{\circ} \mathrm{C}$ for $48 \mathrm{~h}$, then weighed. Scans were analyzed with ImageJ, ver. 1.50a (National Institutes of Health, Bethesda, MD) to determine mean seedling two-dimensional area $\left(\mathrm{cm}^{2}\right)$ for each experimental unit. The enhance contrast function was used at $0.25 \%$ saturated pixels, followed by conversion to an 8-bit binary image, then the analyze particles function (size: $0.01-$ infinity $\mathrm{cm}^{2}$, circularity: $0.00-1.00$ ) to measure the area and generate masks. The masks were visually compared with the original scans to ensure that the software had identified the plant tissue and removed the background. Digital tracing of shoots and roots to the closest millimeter was conducted in ImageJ with the Measure and Label plugin (Rasband, 2006).

Atmospheric water uptake quantification. Based on the observations in GR1, a follow-up experiment was conducted to quantify differences in water uptake from the atmosphere between the substrates. The substrates were oven dried for $72 \mathrm{~h}$ at $80{ }^{\circ} \mathrm{C}$, then $200 \mathrm{~cm}^{3}$ were placed in a 7.3-cm-deep, 7-cm-wide square plastic pot (\#1642; Anderson Die \& Mfg., Co., Portland, OR). There were five replications. The substrates were weighed, and then placed in a chamber with $72 \% \mathrm{RH}$ in a randomized complete block design. After 7 $\mathrm{d}$, the substrates were weighed. Volumetric water content (VMC) was calculated as

$\mathrm{VWC}=\left(\frac{\text { Substrate }_{\mathrm{wet}}-\text { Substrate }_{\text {dry }}}{\text { Substrate }_{\text {volume }}}\right) \times 100$.

Data analyses. Daily germination data were used to create germination curves, calculate a 21-d Timson's index using the formula $\Sigma n$ ( $n=$ cumulative daily germination percentage for each day in the experiment) to measure germination rate and percentage during the experiment (Baskin and Baskin, 2014; Timson, 1965) and determine final germination percentage. Final germination percentage and index data were assessed for normality with residual probability plots, histograms, and skewness and kurtosis calculations (Sileshi, 2012) and homogeneity of variance with Levene's test. Leucanthemum germination percentage data were square root transformed to satisfy normality assumptions.

Germination percentage and index data were analyzed with the general linear model function in Minitab ver. 17.3.1 (Minitab, Inc., State College, PA), with blocks as a random factor. Primary root and shoot length data, two-dimensional area data, and dry weight data were assessed for normality via residual probability plots and homogeneity of variance with Levene's test, and then analyzed with the general linear model function in Minitab, with blocks as a random factor. Post hoc multiple comparisons were conducted via Tukey's studentized range test in Minitab.
Shoot and root length data were correlated with biochar amendment rate. Two-dimensional area was linearly regressed with seedling dry weight and seedling length in Minitab. A multiple regression model was constructed with seedling length and seedling weight as predictors of two-dimensional area. Digital tracing and traditionally collected data were correlated in Minitab.

Water uptake after $7 \mathrm{~d}$ was analyzed as VMC using the general linear model function in Minitab, with block as a random factor. Residual probability plots were generated to confirm normality of data. Post hoc mean separation was performed using Tukey's studentized range test. The significance level $(\alpha)$ used to reject null hypotheses in all statistical tests was 0.05 .

\section{Results and Discussion}

Germination. The biochar used in this study did not have a significant effect on final seed germination percentage for any of the three species (Table 2). These results are similar to the findings with other biochars and their effect on maize, radish, soybean, mung bean, and wheat germination (Free et al., 2010; Solaiman et al., 2012; Van Zwieten et al., 2010) and suggest that coconut shell biochar may be acceptable in seed propagation substrates used for Coreopsis, Eschscholzia, and Leucanthemum.
Eschscholzia germination was higher in GR2 (80.4\%) than in GR1 $(52.8 \% ; P<0.001$; Table 2). A final germination percentage as low as $50 \%$ is consistent with published Eschscholzia germination rates (Montalvo et al., 2002). Eschscholzia is thought to have morphological or morphophysiological dormancies that reduce germination percentages (Baskin and Baskin, 2014; Cook, 1962). Fire and temperature may break Eschscholzia dormancy, with higher germination percentages reported for seeds exposed to liquid and dry smoke or chilling (Montalvo et al., 2002). The higher Eschscholzia germination percentage in GR2 compared with GR1 may have been a result of the seeds being held in cool storage for 4 months between the GR1 experiments and the GR2 experiments. Timson's index data showed no biochar effect (Table 2). Eschscholzia had a higher index in GR2 (1368.8) than GR1 $(895.0 ; P<0.001$; Table 2), which was the result of the high germination rate in GR2. Leucanthemum had a higher Timson's index in GR1 (929.8) than GR2 (674.8; $P<0.001$; Table 2), which was the result of a faster rate of germination in GR1 than GR2.

Shoot and root length. An interaction occurred between GR and biochar with regard to shoot and primary root length for all three species $(P \leq 0.002$; Table 3$)$. Coreopsis, Eschscholzia, and Leucanthemum
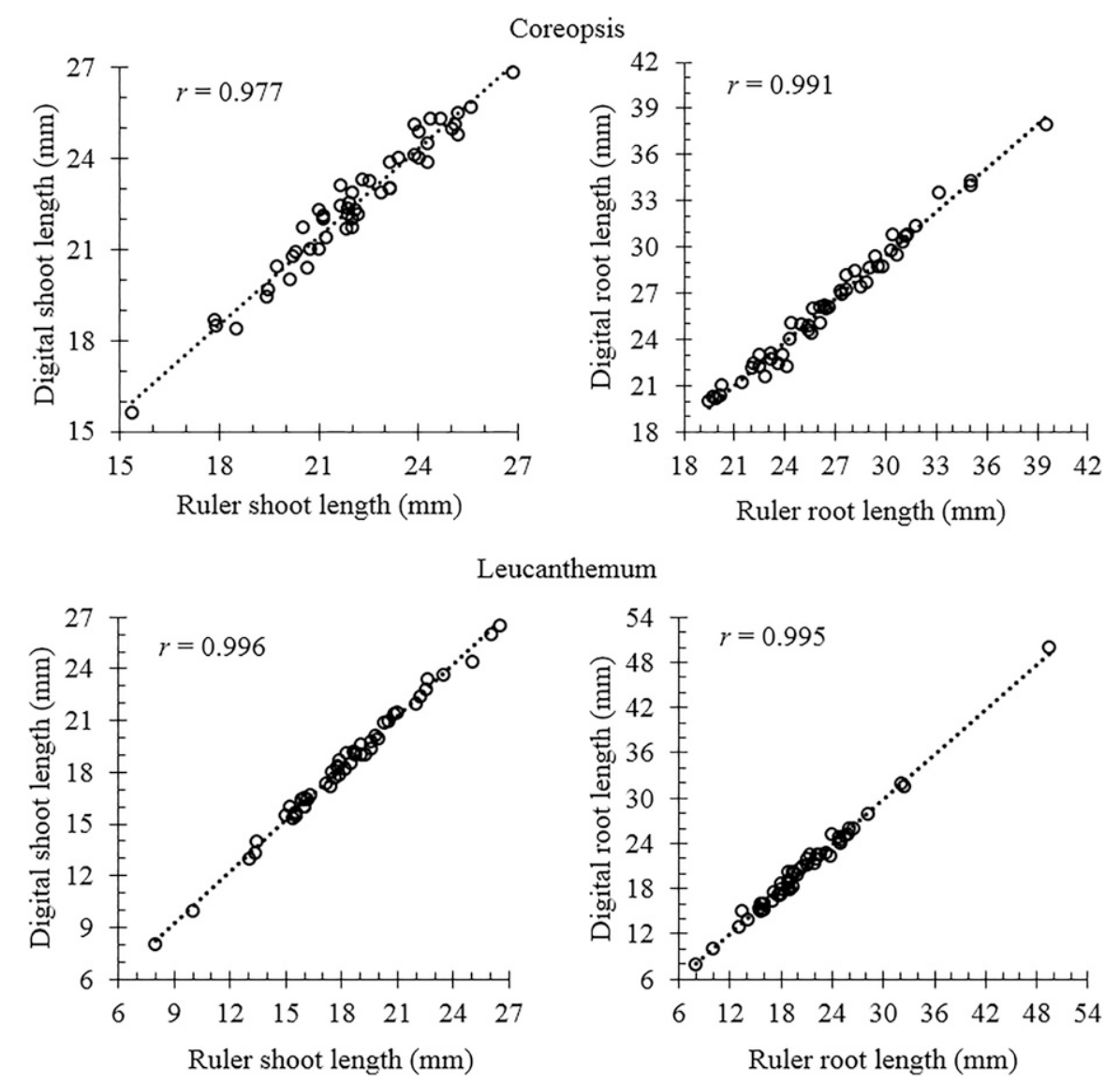

Fig. 3. Correlation of manual ruler measurement and digital tracing measurement of Coreopsis grandiflora and Leucanthemum $\times$ superbum seedling shoot and root lengths in cornell seed germination mix amended with coconut shell biochar $(\mathrm{v} / \mathrm{v})$ after $21 \mathrm{~d}(n=50)$. 
shoot length increased at the three highest rates of biochar amendment compared with the lowest two rates in GR1 $(P \leq 0.05)$, though that response was not repeated in GR2 (Table 3). Primary root length increased with $40 \%$ biochar amendment compared with the control for all three species, and that response was repeated in GR2 $(P \leq 0.05$; Table 3$)$.

Plant growth differences between GRs may have been caused by environmental conditions. The substrate temperatures in both GRs remained in a favorable range for Coreopsis and Leucanthemum germination; however, the GR1 substrate temperatures $\left(24.6{ }^{\circ} \mathrm{C}\right)$ were higher than optimal $\left(21^{\circ} \mathrm{C}\right)$ for subsequent growth (Nau, 2011). This could possibly explain differences in root growth, but it is not probable because the $0 \%$ and $5 \%$ biochar substrates were disproportionately affected. A more likely reason for differences between GRs was water availability.

At the conclusion of the GR1 experiment, leftover substrate stored in containers in the GR exhibited differences in water adsorption as affected by biochar amendment level. This observation prompted an experiment to quantify the amount of water adsorbed from the atmosphere by each substrate. After $7 \mathrm{~d}$, at $72 \%$ atmospheric RH, substrates amended with biochar at a level of $20 \%$ or $40 \%$ had the highest VWC followed by substrates amended with $5 \%$ or $10 \%$ biochar; the control had the lowest VWC $(P \leq 0.05$; Fig. 1). These data suggest that the $40 \%$ biochar substrate experimental unit absorbed $\approx 5.4 \mathrm{~mL}$ water per week more than the control in GR1. When misting was increased to twice weekly in GR2, biochar level did not affect root and shoot growth.

Biochars may be hydrophilic or hydrophobic. The temperature of pyrolysis may affect biochar water adsorption capacity. Pyrolysis at $\approx 600{ }^{\circ} \mathrm{C}$ has produced biochars with high water adsorption capacity (Gray et al., 2014; Kinney et al., 2012), which aligns with the biochar used in this study.

Seedling shoot and root lengths had low to moderate positive correlations with biochar amendment rate for each plant species $(r=0.33-0.54)$. These increases are consistent with reported positive plant growth responses to other biochars (Solaiman et al., 2012; Vaughn et al., 2013). Previous studies have attributed increased plant growth to synergism between biochar and fertilizers (Deenik et al., 2010), biochar-induced plant responses (Graber et al., 2010), microorganism balance (Graber et al., 2010), nutrient availability (Headlee et al., 2014), and improved substrate properties (Alburquerque et al., 2014). This study suggests that water absorption may be another potential benefit, particularly when atmospheric humidity is high and irrigation rate is low.

Dry weight and scans. Propagation substrate amended with $40 \%$ coconut shell biochar increased Coreopsis seedling dry weight $(0.9 \mathrm{mg})$ compared with the control $(0.7 \mathrm{mg}$; $P \leq 0.05)$. Biochar percentage did not affect Leucanthemum seedling dry weight. These mixed results are consistent with similar studies of plant growth responses to biochar incorporation in soils and substrates (Solaiman et al., 2012; Van Zwieten et al., 2010).

Biochar level had no effect on the twodimensional area $\left(\mathrm{cm}^{2}\right)$ of Coreopsis and Leucanthemum; however, seedling dry weight and seedling length (shoot length + primary root length) predicted a significant percentage of the variation in seedling twodimensional area (Fig. 2) for Coreopsis and Leucanthemum. When seedling dry weight and seedling length where combined as a two-factor regression to predict root area, $73 \%$ of the variation in Coreopsis area $\left(R^{2}=\right.$ $0.73 ; P<0.001)$ and $87 \%$ of Leucanthemum area $\left(R^{2}=0.87 ; P<0.001\right)$ could be explained by these factors. The equation for Coreopsis was S-AREA $=0.0125+0.2936$ SDW +0.00784 SL [where S-AREA = seedling two-dimensional area $\left(\mathrm{cm}^{2}\right)$, $\mathrm{SDW}=$ seedling dry weight $(\mathrm{mg})$, and $\mathrm{SL}=$ seedling length $(\mathrm{mm})]$. The equation for Leucanthemum was S-AREA $=0.309+$ $0.2533 \mathrm{SDW}+0.00603 \mathrm{SL}$. These results suggest two-dimensional area provides meaningful data closely allied with more traditional weight and length measurements.

Digitally traced shoot and root lengths were strongly positively correlated $(r=0.99$ $0.97)$ with shoot and root length measurements collected manually with a ruler (Fig. 3). This strong association between manually collected data and digitally collected data suggests both methods are acceptable. The practicality of digital imaging will be influenced by the plant and substrate. In this study, seedlings were easy to scan because substrate was easily removed from roots and the seedling shoots and roots had minimal branching. It was easy to avoid overlapping the plant tissue. Plants with highly developed root or shoot systems would increase the difficulty of collecting digital images free of overlap.

Benefits of digitally collected data include avoidance of handling small, dried samples and the presence of easy-to-store scans for verification or reanalysis of data. Using digital methods for area and length measurements may increase research efficiency by allowing one scan to provide multiple data points. In this study, manual root length data were collected faster than digitally traced data; however, manual root weight data were much slower to collect than digital root area data. When plants appropriate for scanning are paired with multiple metrics per scan, the advantages of digital data collection are substantial.

Not all biochar will be suitable for propagation substrates; however, this study indicates that coconut shell biochar may be used successfully when germinating Coreopsis, Eschscholzia, and Leucanthemum seed. In this study, biochar either had no effect or a minimal effect on seed germination, and it had either no effect or a slightly positive effect on seedling growth. Therefore, coconut shell biochar can maintain the favorable properties of a substrate while displacing ingredients with high economic or ecological cost.

\section{Literature Cited}

Alburquerque, J.A., J.M. Calero, V. Barron, J. Torrent, M.C. del Campillo, A. Gallardo, and R. Villar. 2014. Effects of biochars produced from different feedstocks on soil properties and sunflower growth. J. Plant Nutr. Soil Sci. 177 (1):16-25.

Altland, J.E. and J.C. Locke. 2012. Biochar affects macronutrient leaching from a soilless substrate. HortScience 47:1136-1140.

Bamberg, J.B., R.E. Hanneman, Jr., and L.E. Towill. 1986. Use of activated charcoal to enhance the germination of botanical seeds of potato. Amer. Potato J. 63(4):181-189.

Baskin, C.C. and J.M. Baskin. 2014. Seeds: Ecology, biogeography, and evolution of dormancy and germination. 2nd ed. Academic Press, New York, NY.

Bewley, J.D., K.J. Bradford, H.W.M. Hilhorst, and H. Nonogaki. 2013. Seeds: Physiology of development, germination and dormancy. Springer, New York, NY.

Boodley, J.W. and R. Sheldrake, Jr. 1982. Cornell peat-lite mixes for commercial plant growing. Cornell Coop. Ext. Publ. Info. Bul. 43:1-8.

Brown, R., D. del Campo, A.A. Boateng, M. Garcia-Perez, and O. Masek. 2015. Fundamentals of biochar production, p. 39-62. In: J. Lehmann and S. Joseph (eds.). Biochar for environmental management: Science and technology. Routledge, New York, NY.

Camps-Arbestain, M., J.E. Amonette, B. Singh, T. Wang, and H.P. Schmidt. 2015. A biochar classification system and associated test methods, p. 165-194. In: J. Lehmann and S. Joseph (eds.). Biochar for environmental management: Science and technology. Routledge, New York, NY.

Chan, K.Y., L. Van Zwieten, I. Meszaros, A. Downie, and S. Joseph. 2008. Using poultry litter biochars as soil amendments. Austral. J. Soil Res. 46(5):437-444.

Cook, S.A. 1962. Genetic system, variation, and adaptation in Eschscholzia californica. Evolution 16(3):278-299.

Deenik, J.L., T. McClellan, G. Uehara, M.J. Antal, Jr., and S. Campbell. 2010. Charcoal volatile matter content influences plant growth and soil nitrogen transformations. Soil Sci. Soc. Amer. J. 74(4):1259-1270.

Dumroese, R.K., J. Heiskanen, K. Englund, and A. Tervahauta. 2011. Pelleted biochar: Chemical and physical properties show potential use as a substrate in container nurseries. Biomass Bioenergy 35:2018-2027.

Fenner, M. 1983. Relationships between seed weight, ash content and seedling growth in twenty-four species of Compositae. New Phytol. 95(4):697-706.

Fitzer, E., K-H. Kochling, H.P. Boehm, and H. Marsh. 1995. Recommended terminology for the description of carbon as a solid. Pure Appl. Chem. 67(3):473-506.

Free, H.F., C.R. McGill, J.S. Rowarth, and M.J. Hedley. 2010. The effects of biochars on maize (Zea mays) germination. N. Z. J. Agr. Res. 53(1):1-4

Golzarian, M.R., R.A. Frick, K. Rajendran, B. Berger, S. Roy, M. Tester, and D.S. Lun. 2011. Accurate inference of shoot biomass from high-throughput images of cereal plants. Plant Methods 7(2):1-11.

Graber, E.R., Y.M. Harel, M. Kolton, E. Cytryn, A. Silber, D.R. David, L. Tsechansky, M. 
Borenshtein, and Y. Elad. 2010. Biochar impact on development and productivity of pepper and tomato grown in fertigated soilless media. Plant Soil 337(1):481-496.

Gray, M., M.G. Johnson, M.I. Dragila, and M. Kleber. 2014. Water uptake in biochars: The roles of porosity and hydrophobicity. Biomass Bioenergy 61(1):196-205.

Gross, K.L. 1984. Effects of seed size and growth form on seedling establishment of six monocarpic perennial plants. J. Ecol. 72(2):369-387.

Hartmann, H.T., D.E. Kester, F.T. Davies, Jr., and R.L. Geneve. 2011. Hartmann and Kester's plant propagation: Principles and practice. 8 th ed. Pearson, Saddle River, NJ.

Headlee, W., C.E. Brewer, and R.B. Hall. 2014. Biochar as a substitute for vermiculite in potting mix for hybrid poplar. BioEnergy Res. 7(1):120-131.

Ippolito, J.A., D.A. Laird, and W.J. Busscher. 2012. Environmental benefits of biochar. J. Environ. Qual. 41(4):967-972.

Judd, L.A., B.E. Jackson, and W.C. Fonteno. 2015. Advancements in root growth measurement technologies and observation capabilities for container-grown plants. Plants 4(3):369-392.

Keeley, S.C. and M. Pizzorno. 1986. Charred wood stimulated germination of two fire-following herbs of the California chaparral and the role of hemicellulose. Amer. J. Bot. 73(9):1289-1297.

Kinney, T.J., C.A. Masiello, B. Dugan, W.C. Hockaday, M.R. Dean, K. Zygourakis, and R.T. Barnes. 2012. Hydrologic properties of biochars produced at different temperatures. Biomass Bioenergy 41(1):34-43.

Landis, T.D. and N. Morgan. 2009. Growing media alternatives for forest and native plant nurseries, p. 26-31. In: R.K. Dumroese and L.E. Riley (tech. cords.). Natl. Proc.: Forest and Conservation Assn. 2008 Proc. RMRS-P-58. U.S. Dept. Agr. For. Serv., Rocky Mountain Res. Sta., Fort Collins, CO.

Lehmann, J. and S. Joseph. 2015. Biochar for environmental management: An introduction, p. 1-14. In: J. Lehmann and S. Joseph (eds.). Biochar for environmental management: Science and technology. Routledge, New York, NY.

Leister, D., C. Varotto, P. Pesaresi, A. Niwergall, and F. Salamini. 1999. Large-scale evaluation of plant growth in Arabidopsis thaliana by non-invasive image analysis. Plant Physiol. Biochem. 37(9):671-678.
Liao, S., B. Pan, H. Li, D. Zhang, and B. Xing. 2014. Detecting free radicals in biochars and determining their ability to inhibit the germination and growth of corn, wheat, and rice seedlings. Environ. Sci. Technol. 48(15):85818587.

Liopa-Tsakalidi, A. and P.E. Barouchas. 2017. Effects of biochar on pepperoncini (Capsicum annuum L cv. Stavros) germination and seeding growth in two soil types. Austral. J. Crop Sci. 11(3):264-270.

McLaughlin, H., P.S. Anderson, F.E. Shields, and T.B. Reed. 2009. All biochars are not created equal, and how to tell them apart. Version 2. North Amer. Biochar Conf., Boulder, CO. 16 Aug. 2016. <http://www.biochar-international. org/sites/default/files/All-Biochars-Version2Oct2009.pdf/>.

Montalvo, A.M., L.J. Feist-Alvey, and C.E. Koehler. 2002. The effect of fire and cold treatments on seed germination of annual and perennial populations of Eschscholzia californica (Papaveraceae) in southern California. Madrono 49(4):207-227.

Morley, J. 1927. Following through with grass seed. Natl. Greenskeeper 1(4):8-9, 35.

Morley, J. 1929. Compost and charcoal. Natl. Greenskeeper 3(9):8-10, 11, 26.

Nair, A. and B. Carpenter. 2016. Biochar rate and transplant trat cell number have implications on pepper growth during transplant production. HortTechnology 26:713-719.

Nau, J. (ed.). 2011. Ball redbook, 18 ed. Vol. 2: Crop production. Ball Publishing, West Chicago, IL.

Northup, J. 2013. Biochar as a replacement for perlite in greenhouse soilless substrates. Graduate theses and dissertations. Iowa State Univ. Paper 13399.

Owen, W.G., B.E. Jackson, B.E. Whipker, and W.C. Fonteno. 2016. Pine wood chips as an alternative to perlite in greenhouse substrates: Nitrogen requirements. HortTechnology 26: 199-205.

Paneque, M., J.M. De la Rosa, J.D. FrancoNavarro, J.M. Colmenero-Flores, and $\mathrm{H}$. Knicker. 2016. Effect of biochar amendment on morphology, productivity and water relations of sunflower plants under nonirrigation conditions. Catena 147(1):280-287.

Rasband, W. 2006. Measure and label. 4 Aug. 2014. $<$ https://imagej.nih.gov/ij/plugins/measure-label.html>.
Retan, G. 1915. Charcoal as a means of solving some nursery problems. J. For. 13(1):25-30.

Santiago, A. and L. Santiago. 1989. Charcoal chips as a practical substrate for container horticulture in the humid tropics. Acta Hort. 238 (1):141-148.

Sher-Kaul, S., B. Oertli, E. Castella, and J. Lachavanne. 1995. Relationship between biomass and surface area of six submerged aquatic plant species. Aquat. Bot. 51(1-2):147-154.

Sileshi, G.W. 2012. A critique of current trends in the statistical analysis of seed germination and viability data. Seed Sci. Res. 22(3):145-159.

Smith, M.A.L., L.A. Spomer, M.J. Meyer, and M.T. McClelland. 1989. Non-invasive image analysis evaluation of growth during plant micropropagation. Plant Cell Tissue Organ Cult. 19(2):91-102.

Solaiman, Z.M., D.V. Murphy, and L.K. Abbott. 2012. Biochars influence seed germination and early growth of seedlings. Plant Soil 353 (1):273-287.

Steiner, C. and T. Harttung. 2014. Biochar as a growing media additive and peat substitute. Solid Earth 5(2):995-999.

Sun, Y., B. Gao, Y. Yao, J. Fang, M. Zhang, Y. Zhou, H. Chen, and L. Yang. 2014. Effects of feedstock type, production method, and pyrolysis temperature on biochar and hydrochar properties. Chem. Eng. J. 240(1):574-578.

Tajima, R. and Y. Kato. 2011. Comparison of threshold algorithms for automatic image processing of rice roots using freeware ImageJ. Field Crops Res. 121(3):460-463.

Timson, J. 1965. New method of recording germination data. Nature 207(3):216-217.

Toole, V.K. 1963. Light control of seed germination. Proc. Assn. Offic. Seed Analysts 53 (1):124-143.

U.S. Department of Agriculture. 2016. Floriculture crops 2015 summary. Natl. Agr. Stat. Serv., Washington, DC.

Van Zwieten, L., S. Kimber, S. Morris, K.Y. Chan, A. Downie, J. Rust, S. Joseph, and A. Cowie. 2010. Effects of biochar from slow pyrolysis of papermill waste on agronomic performance and soil fertility. Plant Soil 327(1):235-246.

Vaughn, S.F., J.A. Kenar, A.R. Thompson, and S.C. Peterson. 2013. Comparison of biochars derived from wood pellets and pelletized wheat straw as replacements for peat in potting substrates. Ind. Crops Prod. 51(1):437-443. 